\title{
Thyroid hormone profile after the single dose of iodine-containing contrast agent administration during coronary angiography - prospective study
}

\author{
Sławomir Rychlik ${ }^{1}$, Artur Chmiel ${ }^{1}$, Joanna Wierzbicka-Chmiel ${ }^{1}$, Łukasz Otremba ${ }^{1}$, Wojciech Kreis ${ }^{1}$, Bogdan Marek ${ }^{1,2}$, Dariusz Kajdaniuk ${ }^{1,2}$ \\ 1'Department of Cardiology and Endocrinology, Hospital Rybnik, Poland \\ ${ }^{2}$ Department of Pathophysiology and Endocrinology, School of Medicine in Zabrze, Medical University of Silesia, Katowice, Poland
}

Introduction. Previous studies suggested close relationship between thyroid morphology and the danger of thyroid hormones (THs) disturbances after high single dose of iodine-containing contrast agent. The aim of the study was to assess the prognostic risk factors which influence THs after the cardiac catheterization at patients with coronary artery disease (CAD).

Methods. One hundred twenty patients ( $F / M=40 / 80,59 \pm 11$ years old) without recognized previous thyroid dysfunction and $C A D$ were enrolled between March and October 2015 into the study group I $(\mathrm{N}=70)$ with acute coronary syndrome (ACS) and II group ( $N=50)$ with stable coronary artery disease (CAD), matching to the age. Thyroid function serum parameters (TSH, fT3, fT4), serum concentration of thyroid antibodies (TPO-Ab, Tg-Ab) and thyroid ultrasound were performed before conventional angiography. Hormone status was also evaluated $48 \mathrm{~h}$ and 50 days after catheterization.
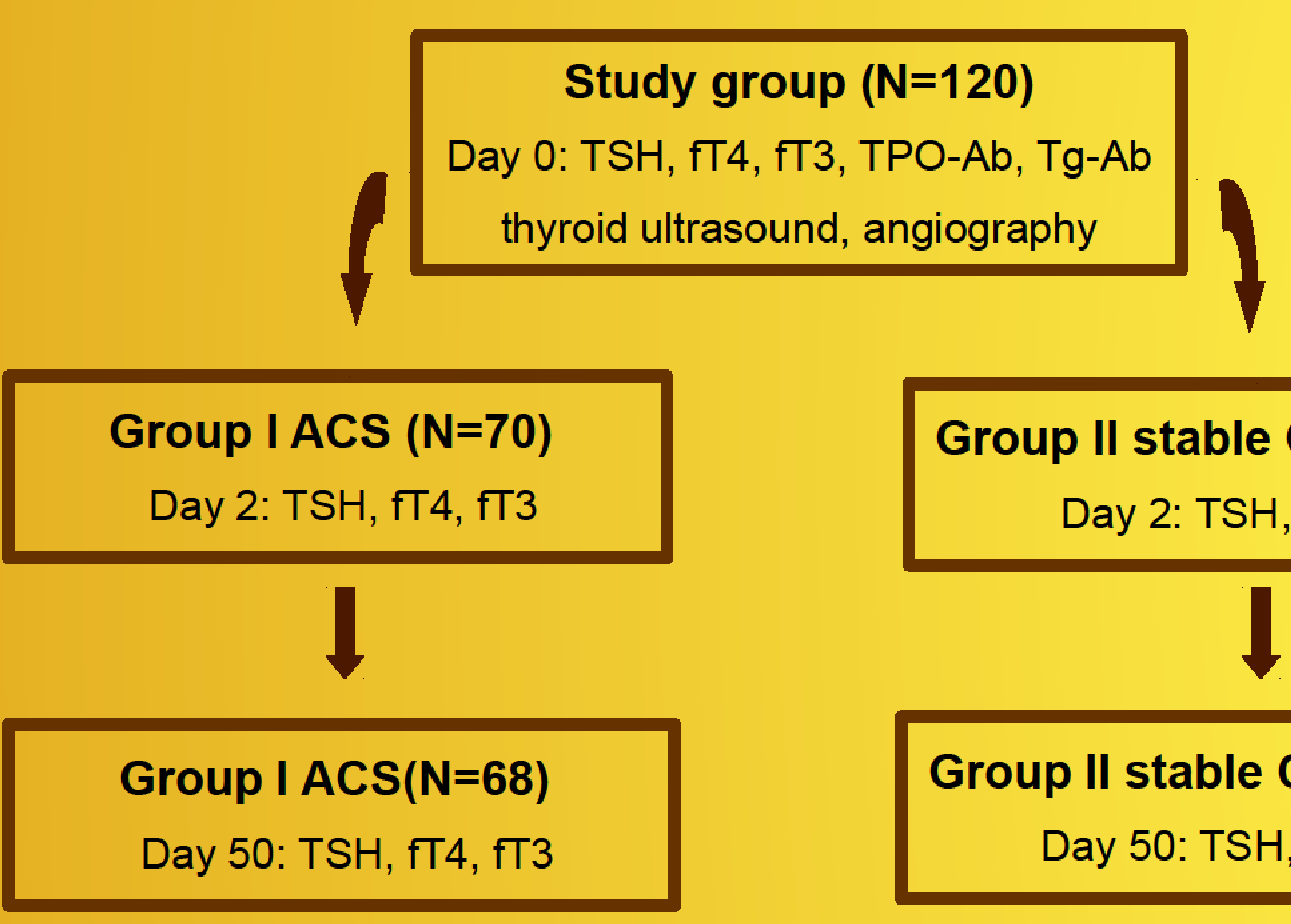

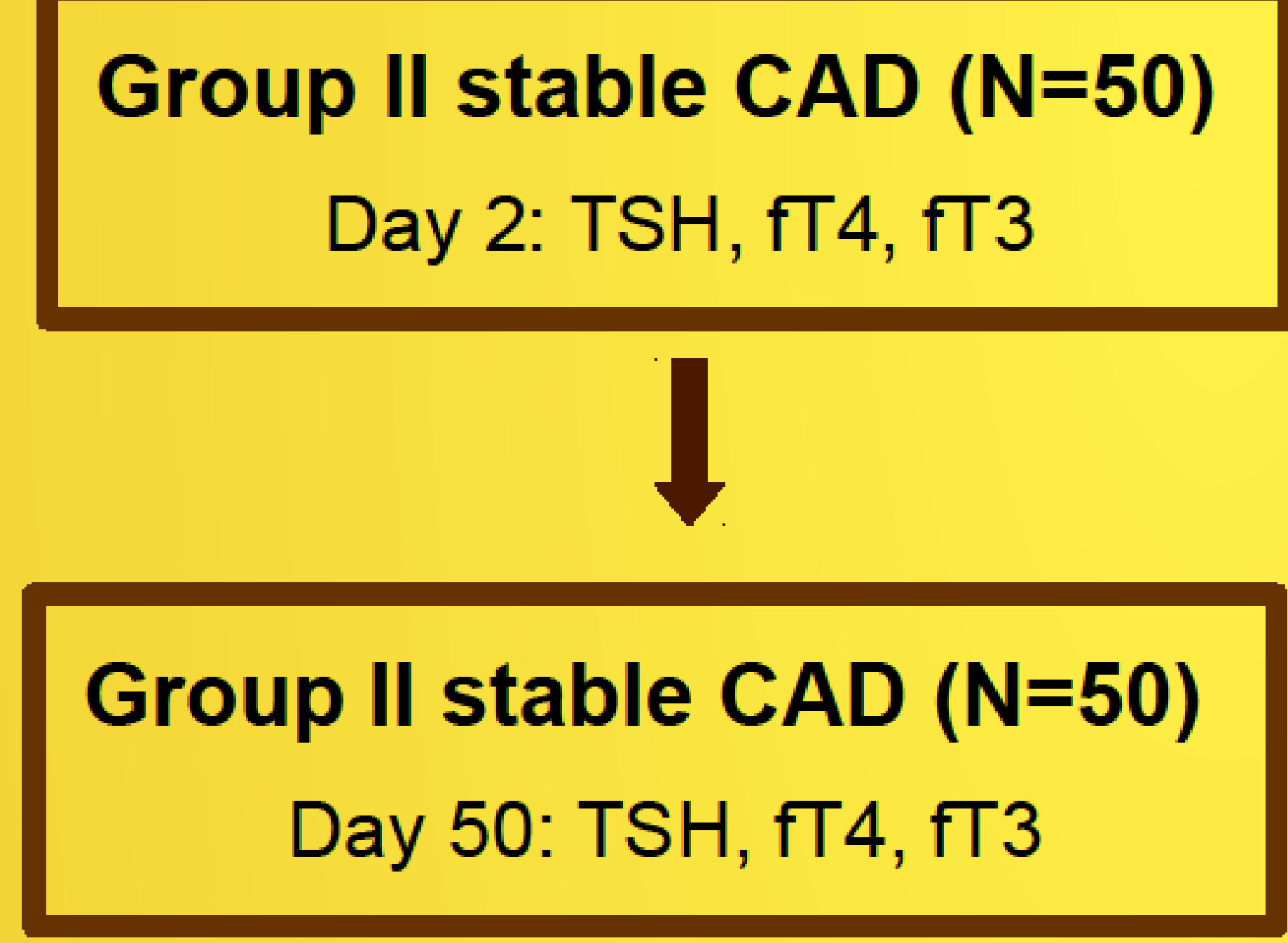

\begin{tabular}{|c|c|c|c|}
\hline $\begin{array}{c}\text { Baseline } \\
\text { characteristics }\end{array}$ & $\begin{array}{c}\text { Group I (N=70) } \\
\text { N (\%) }\end{array}$ & $\begin{array}{c}\text { Group II (N=50) } \\
\text { N (\%) }\end{array}$ & p-value \\
\hline $\begin{array}{l}\text { TSH low/normal/high } \\
{[\mathrm{N}: 0.27-4.20 \mathrm{ulU} / \mathrm{ml}]}\end{array}$ & $\begin{array}{c}0 / 48 / 2 \\
0 / 96 / 4(\%)\end{array}$ & $\begin{array}{c}0 / 67 / 3 \\
0 / 96 / 4(\%)\end{array}$ & 0.69 \\
\hline $\begin{array}{l}\text { fT3 low/normal/high } \\
\text { [N: } 2.00-4.40 \mathrm{pg} / \mathrm{ml}]\end{array}$ & $\begin{array}{c}2 / 47 / 1 \\
4 / 94 / 2(\%)\end{array}$ & $\begin{array}{c}0 / 68 / 2 \\
0 / 97 / 3(\%)\end{array}$ & 0.20 \\
\hline $\begin{array}{l}\text { fT4 low/normal/high } \\
{[\mathrm{N}: 0.93-1.70 \mathrm{ng} / \mathrm{dl}]}\end{array}$ & $\begin{array}{c}2 / 45 / 3 \\
4 / 90 / 6(\%)\end{array}$ & $\begin{array}{c}2 / 66 / 2 \\
3 / 94 / 3(\%)\end{array}$ & 0.64 \\
\hline $\begin{array}{l}\text { TPO-Ab high } \\
{[\mathrm{N}<34 \mathrm{IU} / \mathrm{ml}]}\end{array}$ & $\begin{array}{c}4 \\
(8 \%)\end{array}$ & $\begin{array}{c}3 \\
(4 \%)\end{array}$ & 0.64 \\
\hline $\begin{array}{l}\text { Tg-Ab high } \\
{[\mathrm{N}<125 \mathrm{lU} / \mathrm{ml}]}\end{array}$ & $\begin{array}{c}1 \\
(2 \%)\end{array}$ & $\begin{array}{c}1 \\
(2 \%)\end{array}$ & 0.63 \\
\hline $\begin{array}{l}\text { Thyroid nodules } \\
{[<1 \mathrm{~cm} \text { and } \geq 1 \mathrm{~cm}]}\end{array}$ & $\begin{array}{c}18 \\
(36 \%)\end{array}$ & $\begin{array}{c}26 \\
(37 \%)\end{array}$ & 0.94 \\
\hline
\end{tabular}

Results. At the admission, the subclinical hypothyroidism was recognized at five (4\%) patients, low T3 syndrome in four (2\%), thyroid antibodies at $9(8 \%)$ and thyroid gland nodules at $44(37 \%)$ participants. Two days after angiography the significant decrease of fT3 occurred (mean differences $-0.32 \mathrm{pg} / \mathrm{ml}, \mathrm{p}<0.01$ ) and it was more significant in the group II (time $x$ group interaction $p<0.01$ ). After adjusting for thyroid morphology and thyroid antibodies the differences between groups was still significant $(p=0.04)$, but not after adjusting for the peak value of hs troponin T and hs CRP $(p=0.23)$. The concentration of fT 3 normalized after 50 days in the whole group. The TSH serum concentration was stable after 2 and 50 days after catheterization
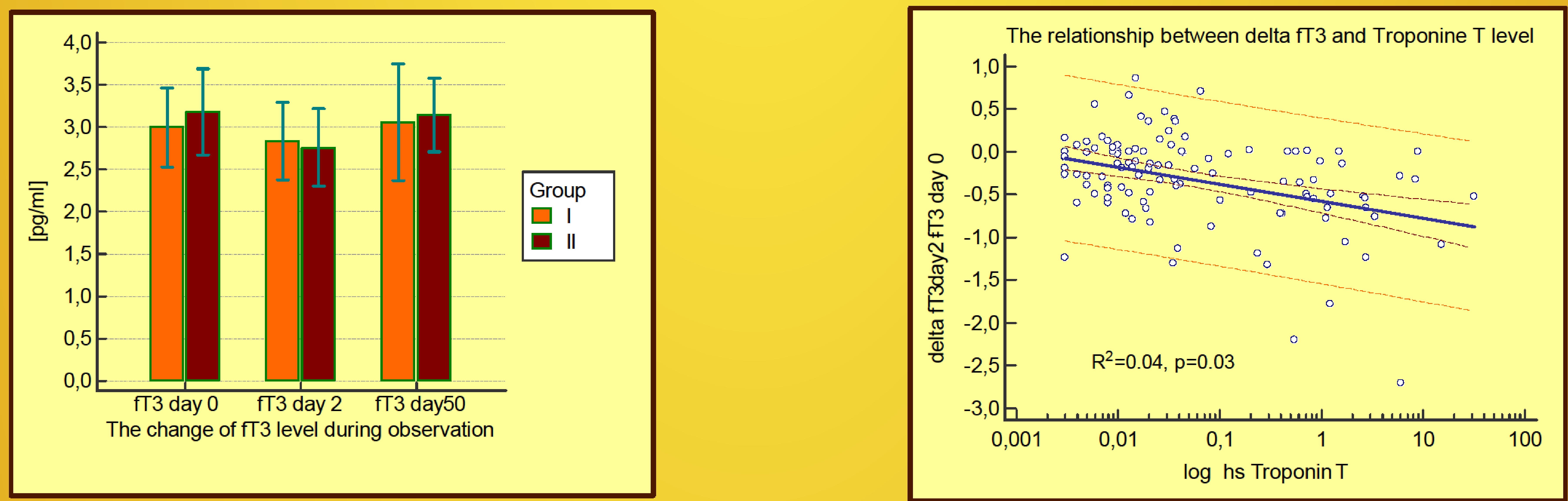

Conclusion. The iodine-containing contrast agent administration during coronary angiography is safe in the aspect of the thyroid function. It was not thyroid morphology but the presence of ACS which influenced THs levels. 